\title{
The Deep-Water Circulation of the Indian Ocean
}

\author{
By A. J. Clowes and G. E. R. Deacon
}

$\mathrm{U}$ JNTL very recently, it has been generally assumed that the deep-water circulation in the Indian Ocean was very similar to that of the Atlantic ; in certain features, such as the Antaretic bottom current and the Antarctic intermediate current, the close resemblance between the two
Gauss also showed that there was a highly saline warm deep layer in the Antarctic and sub-Antarctic regions; and since the data from the intervening part of the ocean were very scanty, it was reasonable to suppose that the warm deep layer found in the south was a continuation of the deep current

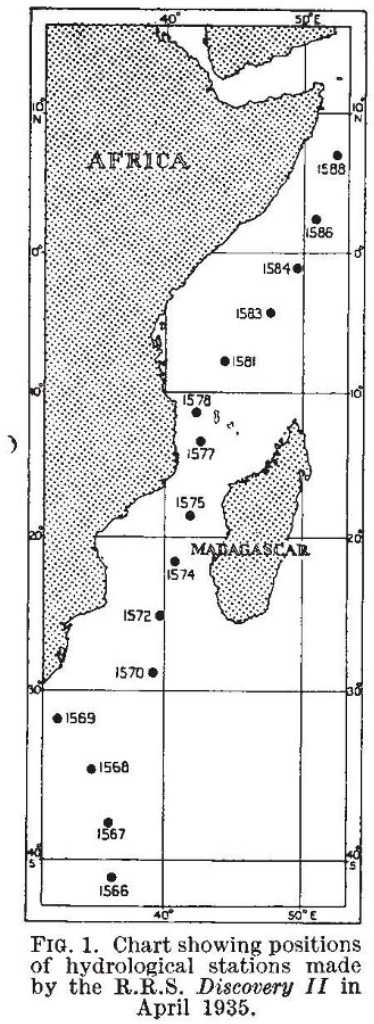

oceans is still undisputed. It has, however, been suggested that the north Atlantic deep currentthe highly saline deep current which Merz and Wüst (1922, p. 23) showed to flow southwards between the intermediate and bottom currents in the Atlantic Ocean-has no parallel in the southern part of the Indian Ocean.

The existence of a southward deep current of highly saline water in the northern part of the Indian Ocean was demonstrated very clearly by Schott (1926), Matthews (1927) and Möller (1929), and it was found to be composed of highly saline surface water sinking from the coastal regions of the Arabian Sea and the neighbouring gulfs, particularly from the Red Sea. The observations made by the Challenger, Valdivia, Planet and

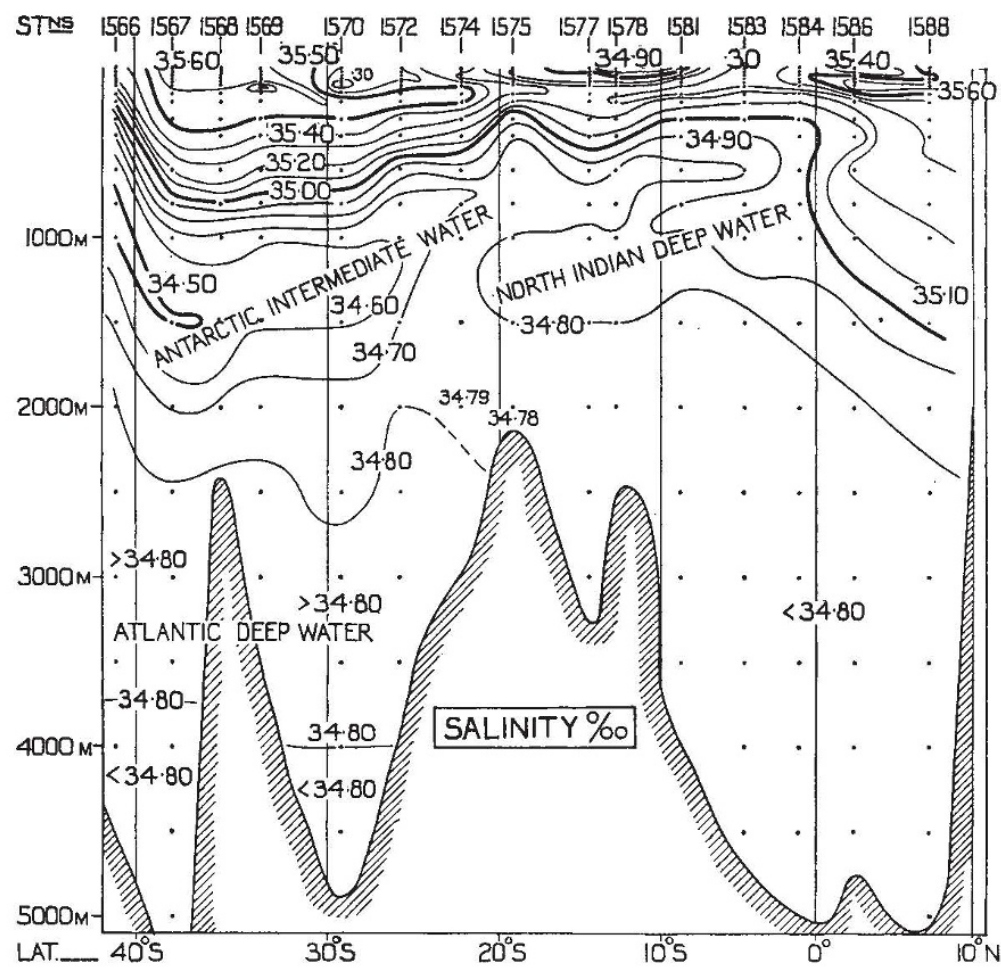

FIG. 2. Salinity at the stations shown in Fig. 1.

which spreads southwards from the north. It was therefore assumed by L. Möller (1929, p. 37) that the north Indian deep current filled the deep layer in the western part of the Ocean with water of salinity more than 34.80 per mille almost as far as the Atlantic-Indian cross ridge in about $50^{\circ} \mathrm{S}$.

Thomsen (1933) has, however, used the observations made by the Dana (1932), and the Willebrord Snellius (1932) in the southern tropical and subtropical parts of the ocean to show that the assumption that the highly saline deep layer in the south was a continuation of the deep current in the north was, after all, not justified. He found that the north Indian Ocean deep current did not carry water with a salinity greater than 34.80 per mille south of a line from the northern end of 


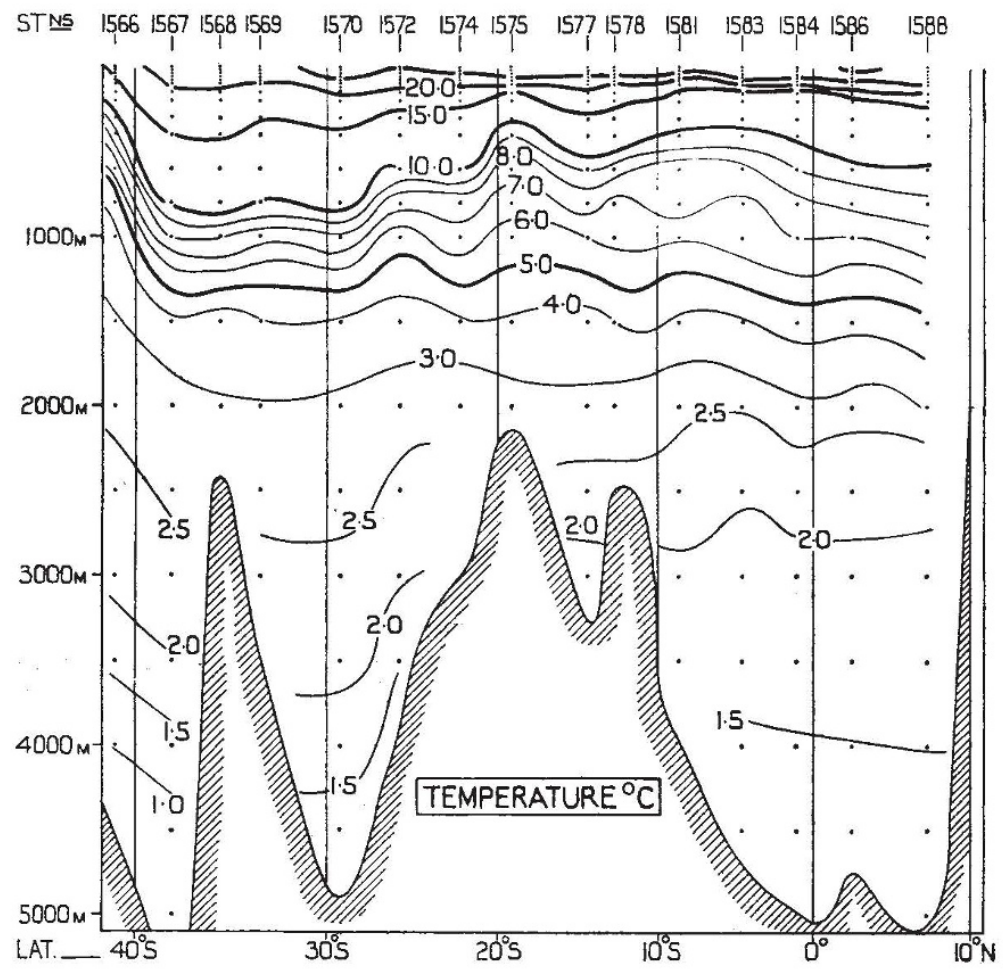

Frg. 3. Temperatures at the stations shown in Fig. 1. shows that it has a salinity of 34.80 per mille as far as $20^{\circ} \mathrm{S}$. approximately. South of this latitude there is a second body of highly saline water with a salinity of more than 34.80 per mille, but it is clear from the salinity, temperature and oxygen content that this second body of highly saline water is not merely a continuation of the north Indian deep current. It is approximately $2^{\circ} \mathrm{C}$. colder and 2 c.c. per litre richer in oxygen, and is therefore derived partly from another source, plainly from an eastward current of Atlantic deep water. The existence of such a current is in fact generally agreed upon. It was inferred by Merz and Wüst (1922, p. 23) from the temperature chart for 1500 fathoms given by Buchan (1895) in the Challenger reports, and also recognised by Wüst (1926, p. 250) and Möller (1929, p. 37).

Although there is this body of

Madagascar to Ceylon. L. Möller (1933) was not convinced that the new data which Thomsen used justified at present a reversal of her former conclusions. In a later paper, Thomsen (1935, p. 299) states that at stations on a line between Ceylon and Cape Delgado he found no traces of a deep current between $2000 \mathrm{~m}$. and $3000 \mathrm{~m}$., but that it is possible that a rudimentary, southerlydirected current exists with a nucleus at about $800 \mathrm{~m}$. in the north and about $1200 \mathrm{~m}$. in the south.

Further light has been thrown upon the problem by a series of observations made by the R.R.S. Discovery $I I$ in her recent voyage from the Antarctic in 1935 on a line from Marion Island through the Mozambique Channel to the Gulf of Aden. The positions of the stations and preliminary salinity, temperature and oxygen content sections are shown in Figs. 1-4. The north Indian deep water is clearly distinguished at the northern end of the sections by its high temperature and high salinity, and low oxygen content. The salinity section (Fig. 2)

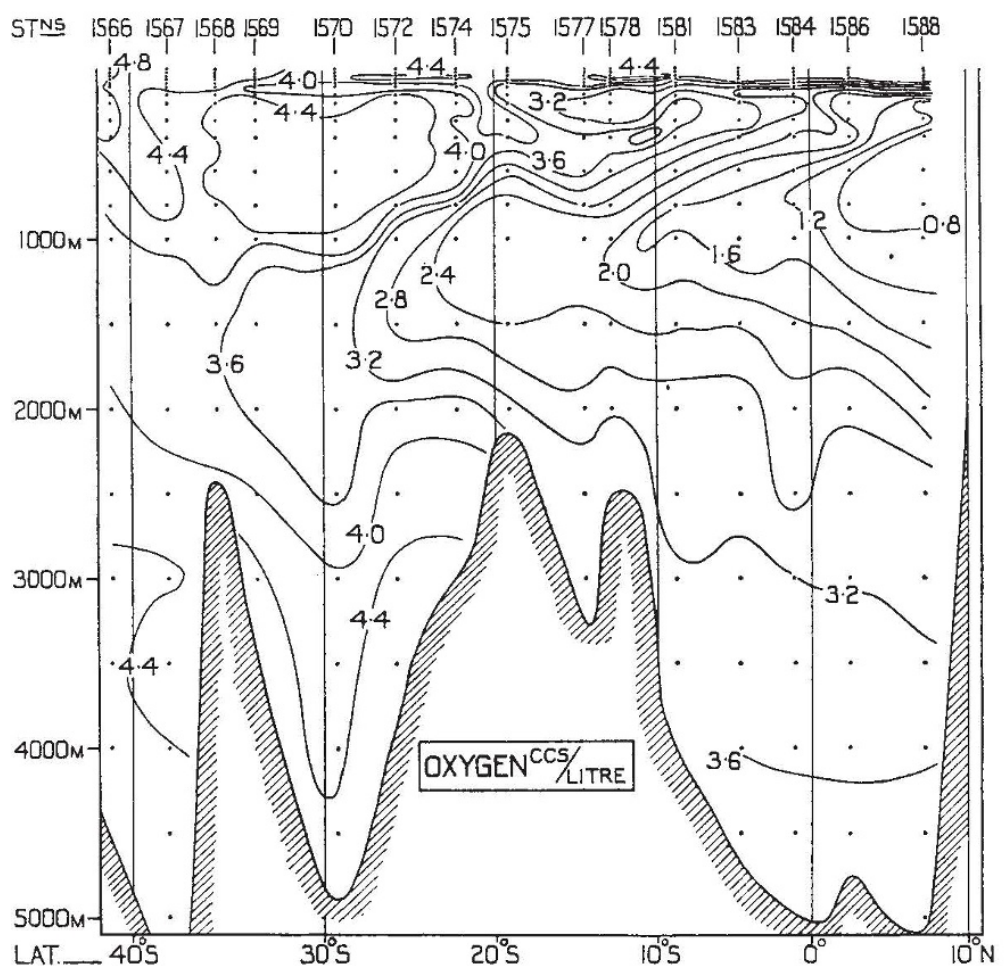

FIG. 4. Oxygen content at the stations shown in Fig. 1. 
distribution, especially, suggests that the north Indian deep water flows much farther south in the upper stratum of the warm deep layer, sandwiched between the Antarctic intermediate current and the Atlantic water. A chart of the oxygen distribution in the warm deep layer in the southern part of the Indian ocean, to be published in a forthcoming report by one of us (G.E.R.D.), shows that south of Africa the oxygen content of the deep layer falls rapidly towards the east, indicating that the Atlantic water is joined by a southward movement of water containing less oxygen from the northern part of the Indian Ocean.

A comparison of our section with that of Möller (her Mozambique section is along almost the same line as ours) suggests that the volume and salinity of the north Indian deep current are subject to large variation, probably related to the changes of salinity in the coastal regions and to the current differences brought about by the changes of the monsoon winds and variation in the south Equatorial current. The observations of the Valdivia and the Ormonde used by Möller show that the deep current fills the northern part of the Ocean with water of 35.00 per mille salinity as far as $8^{\circ} \mathrm{S}$. and to a depth of $2000-2500$ metres, while our section (Fig. 2) shows that this isohaline is not found south of the equator or deeper than 1500 metres. A strict comparison cannot be made between Thomsen's and our section, since his is much farther east than ours, but the volume of the deep current seems to have been less when his observations were made, since he did not find the 34.80 per mille isohaline south of a line from Ceylon to Cape Delgado (1933, p. 78), whereas we found it to extend as far as $20^{\circ} \mathrm{S}$.

Thus, as a result of the recent observations of the R.R.S. Discovery II, the extent of the southward flow of the north Indian deep current appears to be a compromise between the views of Möller and Thomsen. Oxygen observations in particular show (Fig. 4) that this current can be traced southwards as a tongue of poorly oxygenated water sandwiched between Antarctic intermediate water and an eastward current of north Atlantic deep water.

\section{REFERENCES}

Buchan, A., "Report on Oceanic Circulation", Summary of the Scientific Results of the Voyage of H.M.S. Challenger, 2, map $13 ; 1895$. Matthews, D. J., "Temperature and Salinity Observations in the

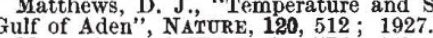

Gulf of Aden", NATURE, 120, $512 ; 1927$. Z. Gerz, Ardk. Berl., 1-35; 1922 .

Me. Griler, L., "Die "Zirkulation des Indischen Ozeans", Veröff. Inst. Meeresk. Univ. Berl., 21, 1-48; 1929.

Möller, L., "Zur Frage der Tiefenzirkulation im Indischen Ozean", Ann. Hydrogr. Berl., 61, 233-236; 1933.

van Riel, P. M., "Einige ozeanographische Beobachtungen im Roten Meer, Golf von Aden und Indischen Ozean", Ann. Hydrogr. Berl., 60,

Schmidt, J., “Dana's Togt omkring Jorden 1928-1930”, København; 1932.

Schott, G., "Die Tiefenwasserbewegungen des Indischen Ozeans", Ann. Hydrogr. Berl., 12, 417-431; 1926.

Thomsen, H., "The Circulation of the Indian Ocean", J. Cons. inst. Explor. Mer., 8, 73-79; 1933.

Thomsen, H., "Enstehung und Verbreitung einiger charakteristischer Wassermassen in dem Indischen und sudlichen Pazifischen Ozean", Ann. Hydrogr. Berl., 63, 293-305; 1935.

Wüst, G.," "Zweiter Bericht über die ozeanographischen Untersuchungen", Z.'Ges. Erdk. Berl., 231-250; 1926.

\title{
A Century of Botany* $1835-1885-1935$
}

\author{
By Prof. F. O. Bower, F.R.S.
}

$\mathrm{I}^{\mathrm{N}}$ 1835 Glasgow already possessed a botanic garden, which had been established in 1818 by Royal Charter. In this same year, the regius chair had also been founded. It was occupied in 1835 by its greatest tenant, Sir William Hooker, who after holding it for twenty years became, in 1841, the first director of the Royal Botanic Gardens at Kew. He was succeeded in that office by his son, Sir Joseph Hooker, who had been educated in this University. Thus Glasgow may be held as the cradle of the national establishment. Under the care of the professor, the Royal Botanic Garden of Glasgow had become a centre of high horticulture, and of the distribution of rare plants, many of them new to science. But there was in

\footnotetext{
* From an address delivered on November 8 in the University of Glasgow by invitation, in celebration of the jubilee of Prof. Bower's appointment as regius professor of botany (April 1, 1885) and of Prof. Bower's eightieth birthday (November 4, 1935).
}

1835 no Department of Botany in the old College. There were no laboratory, botanical museum, herbarium, or library, beyond what Hooker himself possessed, which was accommodated in his own private house. So when he was appointed as the first Director of Kew in 1841 he naturally took his collections with him, leaving the University wholly denuded; though Kew itself absorbed thus the finest private collections in the country.

A brief survey may be made of the state of botanical science in the world at large in 1835, when Sir William Hooker was in his fifteenth year of office at Glasgow, and in the full plenitude of his powers as a man of fifty. Nothing can be more revealing of the time than that while it was pre-evolutionary, it was also pre-protoplasmic. Though plant anatomy was well advanced, with 